\title{
The role of the Panamanian land bridge during the initial colonization of the Americas
}

Georges A. Pearson \& Richard G. CoOKE*
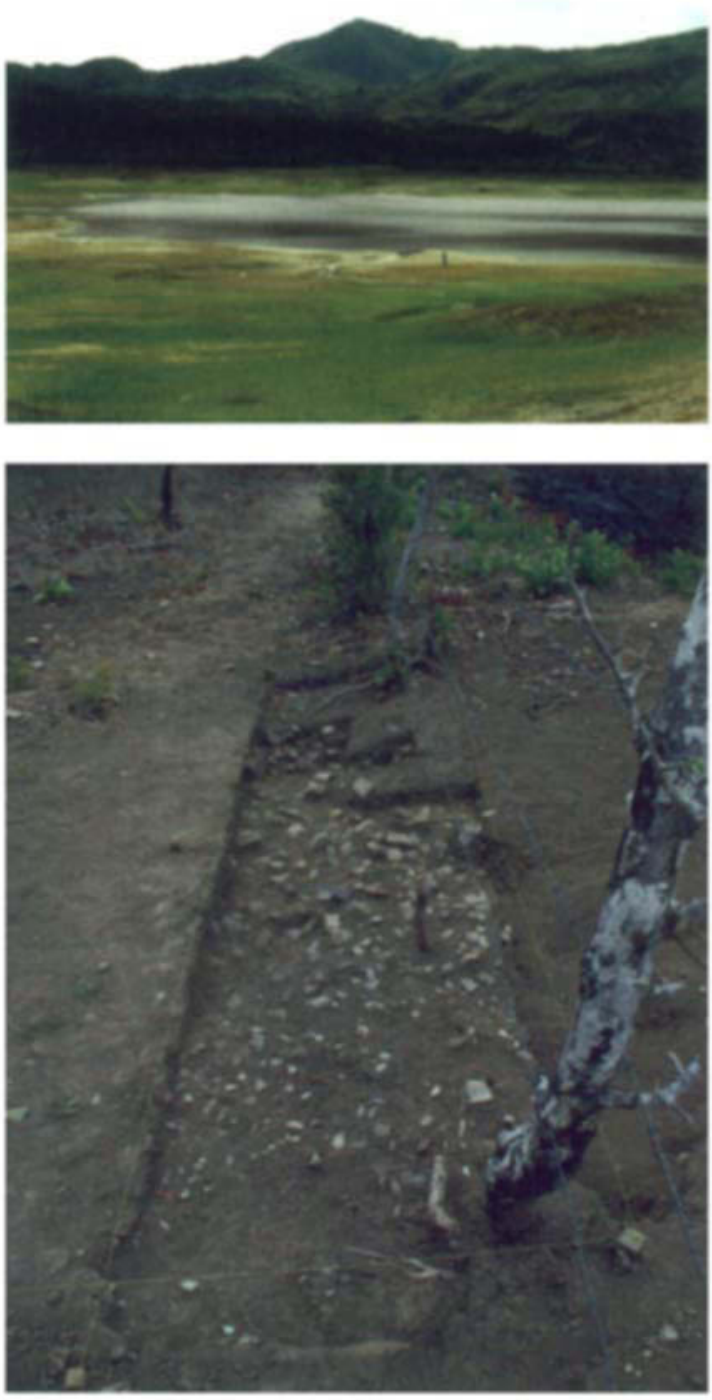

FIGURE 1 (top). Lake La Yeguada during month of April when water level is at its lowest.

FIGURE 2 (bottom). Excavations at the Nieto quarry/ workshop exposing dense concentration of manufacturing debris.
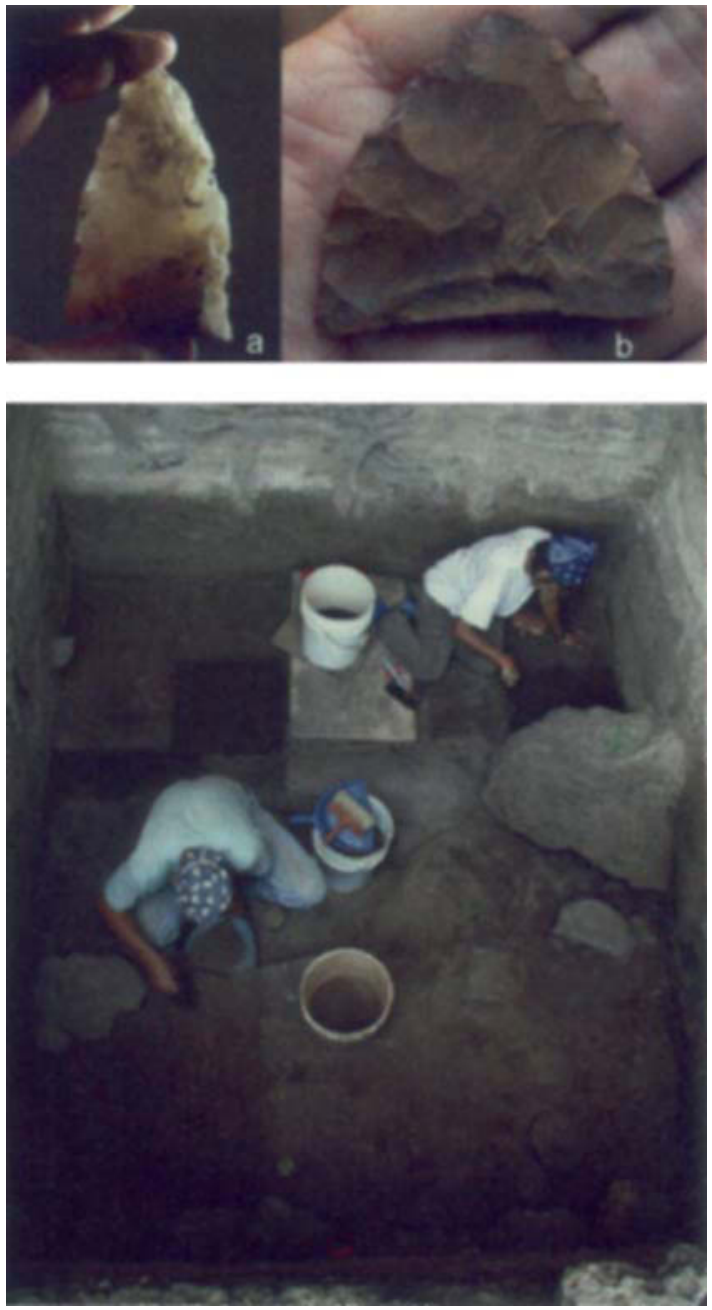

FIGURE 3 (top). 3a Broken Clovis-like point perform made on translucent quartz from Nieto quarry. $3 \mathrm{~b}$ Tip of fluted point made on yellow jasper from Cueva de Los Vampiros.

FIGURE 4 (bottom). Excavations at Cueva de Los Vampiros.

* Pearson, Department of Anthropology, University of Kansas, 622 Fraser Hall, Lawrence KS 66045, USA. ftgap@ku.edu georges_pearson@hotmailcom Cooke, Smithsonian Tropical Research Institute, Unit 0948, APO AA, 34002-0948. cooker@naos.si.edu

ANTIQUITY 76 (2002): 931-2 
Since 1999, an on-going survey project in Panama has succeeded in locating traces of late Pleistocene-early Holocene humans who colonized the Americas. To date, our investigation has focused on three environmental zones found on the Pacific side of the continental divide - the highlands, the interior and the coast. The goal of this project is to link the early archaeological records of North and South America which still remain isolated on many levels. Although some Palaeoamerican lithic assemblages from North and South America show clear technological sinilarities, the historical, genetic and even chronological relationships between these early populations are still the subjects of debate. Fortunately, the narrowness of the Isthmus of Panama and its axial location between the continents afford an uncommon advantage for archaeologists trying to understand north-south relationships between the larger land masses. Our main objective was to find stratified occupations containing diagnostic tools normally associated with either north or south Palaeoamerican groups and determine how these compared, both technologically and chronologically, with their respective homologues on opposite continents.

The survey began around Lake La Yeguada, at an elevation of $650 \mathrm{~m}$ (FIGURE 1). This area was chosen for study based on the results of pollen cores taken from the lake, which contained large amounts of particulate carbon dating around 11,000 BP and attributed to human disturbance (Piperno et al. 1990; Bush et al. 1992). The survey identified several early sites around the lake's shore as well as 10 quarry/workshops, various lithic raw material sources and rock-shelters in the immediate area. Diagnostic artefacts included scatters of bifacial thinning flake, finished points and broken performs.

Next, we located an ancient quarry/workshop in the middle of the Azuero Peninsula. The Nieto site is associated with a large quartz vein that juts out of a small hilltop. Both surface collections and excavations were carried out at the quarry (FIGURE 2). Charcoal samples were not recovered due to the shallowness of the deposits and the risk of contamination from on-going slash-and-burn cultivation next to the site. Nevertheless, Clovis-like point performs (FIGURE 3a) and other diagnostic tools found among the manufacturing debris indicate that Palaeoamericans frequently visited this source to procure translucent stone.

Finally, we excavated at Cueva de Los Vampiros which is situated on an inselberg, approximately $3 \mathrm{~km}$ from the mangrove-lined coast of Parita Bay. The cave appears to be part of a complex of cavities and interconnecting tunnels that have dug into this isolated geological feature. The site was first discovered 20 years ago during the Proyecto Santa Maria survey (Cooke \& Ranere 1984). Although initial test pits did not find any diagnostic artefacts, the discovery of bifacial thin- ning flakes associated with a date of $8560 \pm 160$ (Beta5101) showed promise.

New excavations between January and May 2002 have now revealed the existence of a fluted point occupation at the base of its cultural deposits (FTGUREs $3 \mathrm{~b}, 4)$. Thus far, only a few charcoal samples have been analysed. Initial radiocarbon results from above and immediately below the fluted point assemblage have bracketed this occupation between $c .11,500$ and 9000 $\mathrm{BP}$. It is interesting to note that, although the cave was later used during Precolumbian times as a fish-processing locality, its Pleistocene occupants would have had to walk over $80 \mathrm{~km}$ to reach the Pacific.

Recent discoveries at Cueva de Los Vampiros mark the third occurrence of diagnostic early Palaeoamerican artefacts found in a buried context between the Rio Grande and Columbia (an area encompassing 2,509,000 sq. km). Indeed, before we initiated this survey project only two localities, the Los Grifos cave in Mexico (Santamaria 1981) and the Los Tapiales site in Guatemala (Gruhn \& Bryan 1977), claimed similar findings.

Current research on the Isthmus of Panama is attempting to build an information bridge to join the early archaeological records of North and South America. Future excavations at Vampiros cave will help us understand if the Isthmian region acted as a cultural filter, a zone of contact or simply a springboard for rapid cultural diversification. Ultimately, continued investigations into the Pleistocene period of Middle America will help provide a Pan-American perspective on the peopling of the New World.

Acknowledgements. Many people and institutions have contributed towards the success of our project. We especially want to thank Robert A. Beckwith and Diana Carvajal for their assistance in the field. We are also indebted to Carlos Fitzgerald and Patrimonio Historico of Panama. Funding for this project was provided by Fellowships from the Smithsonian Tropical Research Institute and a Dumbarton Oaks Project Grant.

\section{References}

Bush, M.B., D.R. Piperno, P.A. Colinvaux, P.E. De Oliveira, L.A KRISSEK, M.C. MTLIFR \& W.E. ROWE. 1992. A 14,300-yL paleoecological profile of a lowland tropical lake in Panama, Ecological Monographs 62: 251-75.

COOKE, R. \& A.J. RANERE. 1984. The 'Proyecto Santa Maria': a multidisciplinary analysis of prehistoric adaptations to a tropical Watershed in Panama, in F.W. Lange (ed.), Recent developments in Isthmian archoeology: advances in the prehistory of lower Central America: 3-30. Oxford: British Archaeological Reports. Intemational series S212.

GruHN, R. \& A.L. Bryan, 1977. Los Tapiales: a Paleo-indian campsite in the Guatemala highlands, Proceedings of the American Philosophical Society 121(3): 235-73.

PIPERNO, D.R., M.B. BUSH \& P.A. COLINVAUX. 1990. Paleoenvironments and human occupation in late-Glacial Panama, Quaternary Research 33: 108-16.

SANTAMARIA, D. 1981. Preceramic occupations at Los Grifos rock shelter, Ocozocoautla, Chiapas, Mexico, in J. Garcia-Barcena \& F. Sanchez Martinez (ed.), X Congreso of the Union Internacional de Ciencias Prehistoricas y Protohistoricas: 6383. Mexico: UNESCO. 